\title{
CrimRxiv
}

\section{A Peek into Their Mind? An Exploration of Links Between Offense- Supportive Statements and Behaviors among Men Who Sexually Exploit Children and Adolescents Online}

Sarah Paquette, Francis Fortin

Published on: Mar 03, 2022

License: Creative Commons Attribution 4.0 International License (CC-BY 4.0). 
